\title{
Pemphigoid Antibody Measurement
}

National Cancer Institute

\section{Source}

National Cancer Institute. Pemphigoid Antibody Measurement. NCI Thesaurus. Code C81988.

The determination of the amount of pemphigoid antibodies present in a sample. 